\title{
Do anti-amyloid beta protein antibody cross reactivities confound Alzheimer disease research?
}

\author{
Sally Hunter *i] and Carol Brayne
}

\begin{abstract}
Background: Alzheimer disease (AD) research has focussed mainly on the amyloid beta protein (A $\beta$ ). However, many A $\beta$-and P3-type peptides derived from the amyloid precursor protein (APP) and peptides thought to derive from $A \beta$ catabolism share sequence homology. Additionally, conformations can change dependent on aggregation state and solubility leading to significant uncertainty relating to interpretations of immunoreactivity with antibodies raised against $A \beta$. We review evidence relating to the reactivities of commonly used antibodies including 6F3D, $6 \mathrm{E} 10$ and $4 \mathrm{G} 8$ and evaluate their reactivity profiles with respect to AD diagnosis and research.

Results: Antibody cross-reactivities between A $\beta$-type, P3-type and A $\beta$-catabolic peptides confound interpretations of immunoreactivity. More than one antibody is required to adequately characterise $A \beta$. The relationships between anti-A $\beta$ immunoreactivity, neuropathology and proposed APP cleavages are unclear.

Conclusions: We find that the concept of A $\beta$ lacks clarity as a specific entity. Anti-A $\beta$ antibody cross-reactivities lead to significant uncertainty in our understanding of the APP proteolytic system and its role in AD with profound implications for current research and therapeutic strategies.
\end{abstract}

Keywords: Alzheimer disease, Amyloid beta protein, Amyloid precursor protein, Antibody, Cross reactivity, Experimental design

\section{Introduction}

Research into the causes and progression pathways of Alzheimer disease (AD) has focussed primarily on the roles of the amyloid beta protein $(A \beta)$ derived from the amyloid precursor protein (APP) via sequential proteolytic cleavages $[1,2]$. In summary, there are two main APP cleavage pathways, Fig. 1 . The $\alpha$-pathway involves an initial $\alpha$-cleavage to release the large extracellular soluble sAPPa leaving the 83 amino acid (aa) residue carboxy terminal fragment (CTF) in the membrane. This is further processed by $\gamma$-secretase containing Presenilin (PS) to release the variable length P3 peptide and the APP intracellular domain (AICD). This pathway is thought to be constitutive and $\alpha$-cleavage precludes processing by the $\beta$-secretase BACE1 as it cuts within the $\mathrm{A} \beta$ sequence. In competition with $\alpha$-cleavage and with

\footnotetext{
* Correspondence: seh66@medschl.cam.ac.uk

Department of Public Health and Primary Care, Institute of Public Health Forvie Site, University of Cambridge School of Clinical Medicine, Box 113 Cambridge Biomedical Campus, Cambridge CB2 OSP, UK
}

APP expression as rate limiting [3], $\beta$-cleavage releases the large extracellular soluble sAPP $\beta$ leaving a 99 aa residue CTF in the membrane that is further processed by the shared sequential $\gamma$-secretase to release the variable length $A \beta$ and the AICD. The main fragments expressed are the large sAPP $\alpha$ and sAPP $\beta$ domains, the smaller variable length $A \beta$ and $P 3$ fragments and the AICD, all sharing sequence homology to varying degrees with each other and with full length APP. Additional APP cleavages include $\beta$ '-cleavage by BACE2 [4], $\delta$ - and $\eta$-cleavage $[5,6]$ and cleavage by caspase [7]. BACE2 may also be involved in catabolism of $\mathrm{A} \beta$ [8].

Evidence relating to $A \beta$ from autosomal dominant genetic mutations in the amyloid precursor protein (APP) and presenilins (PS) in familial AD (FAD) [9, 10], coupled with the neuropathological diagnostic value associated with the presence of deposits of $A \beta$ in the brain in both FAD and sporadic AD (SAD) [11, 12], has been interpreted in the amyloid cascade hypothesis as showing a causal role for $A \beta$ in disease progression $[13,14]$ 


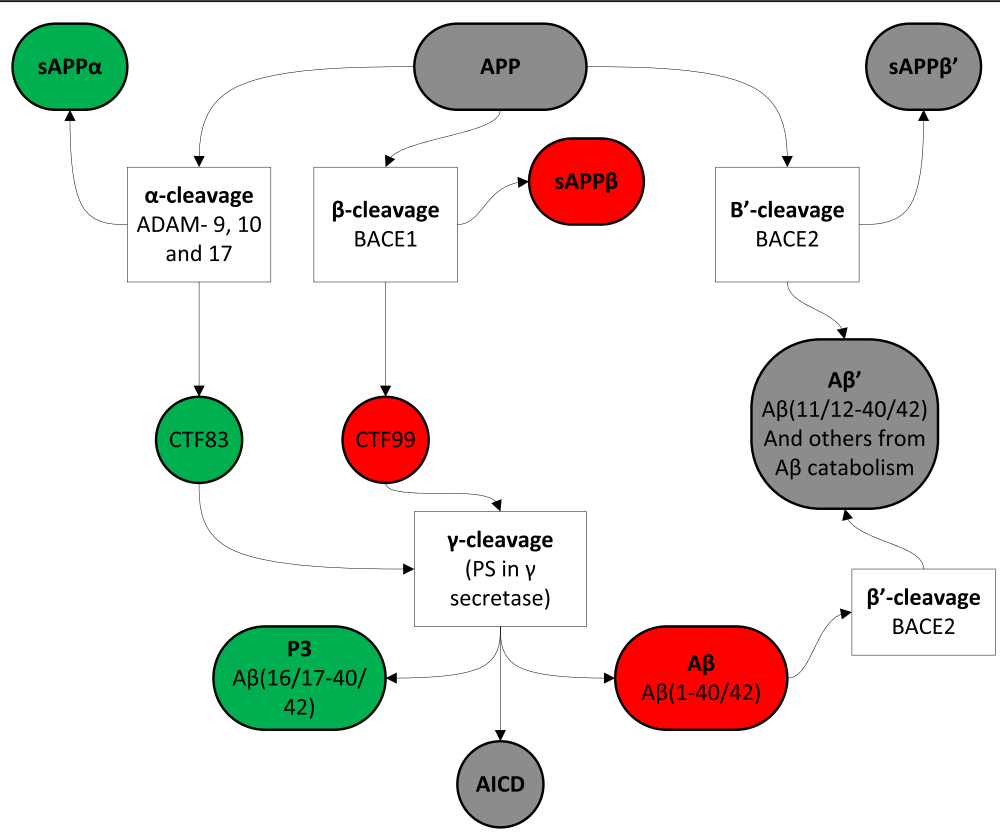

Fig. 1 APP cleavage pathways. Green: sequential $\alpha$ - and $\gamma$ - cleavages of the $\alpha$ - pathway, red: sequential $\beta$ - and $\gamma$ - cleavages of the $\beta$ - pathway, grey: alternative fragments from $\beta^{\prime}$ cleavage or shared full length APP and AICD. Other cleavage pathways such as $\delta$ and $\eta$ are not shown

and has been updated to reflect the ratios of $\mathrm{A} \beta(1-42) /$ A $\beta(1-40)[14,15]$ or oligomers $[16,17]$. However, this interpretation of the evidence relating to $A \beta$ has not been fully accepted and alternative interpretations including the presenilin hypothesis $[18,19]$ and the APP matrix approach $[20,21]$ have been put forward.

In addition to $A \beta 40$ and $A \beta 42$, the peptides at the main focus of research, there are many soluble [22] and insoluble $\mathrm{A} \beta$-type peptides, including $\mathrm{N}$-terminal extended peptides [23], that have yet to be fully described and accounted for in theoretical and experimental disease models. In addition to different sequences, $A \beta$ type peptides can exist in a variety of aggregation states including monomers, dimers, oligomers and fibrils. Evidence that behaviour profiles differ between the various $A \beta$-type sequences and aggregation states suggests that some $A \beta$ species, such as $A \beta 42$ or oligomers, may be more important in disease progression than others.

Evidence from population studies [24-26] suggests that correspondence between clinical dementia status and neuropathological diagnosis blind to clinical dementia status in the older population where most dementia occurs, do not correspond well. The relationships between $A \beta$, neuropathology and clinical dementia status are not clear. In order to investigate these relationships an understanding of the different presentations of $A \beta$ across the different sequence lengths, aggregation states and neuropathological associations is required.

$\mathrm{AD}$ research has depended greatly on the use of antibodies. Concerns regarding the interpretation and reliability of antibodies relating to reproducibility of science in general have been previously highlighted [27]. Antibodies have been raised against various $A \beta$ epitopes and these recognise slightly different pathological profiles [28-31]. Because A $\beta$-type peptides share sequence homology and conformations to varying degrees, cross reactivity can potentially confound interpretations of immunoreactivity. Here we look at evidence relating to the reactivities of the commonly used antibodies 6F3D, 6E10 and 4G8 immunoreactive with $A \beta$ and ask how the reactivity profiles of commonly used antibodies relate to $\mathrm{AD}$ diagnosis and research.

\section{Antibody reactivities with peptides from $\alpha-, \beta$ - and $\gamma$ - cleavages}

The epitopes recognised by 6F3D, 6E10 and 4G8 to various forms of $A \beta$, Fig. $2 \mathrm{a}$ and Table 1, are usually interpreted to be sequence specific and relate to proteolytic fragments released following sequential $\beta$ - and $\gamma$-cleavages.

$6 \mathrm{E} 10$ recognises an epitope in the $\mathrm{N}$-terminal region of both $A \beta 40$ and $A \beta 42$. The $6 \mathrm{E} 10 \mathrm{~N}$-terminal epitope is also recognised in $A \beta(1-16 / 17)$, a fragment that could reflect catabolism of $A \beta[3,32]$, or additional processing of the C99 carboxy terminal membrane bound fragment (CTF) following $\beta$-cleavage [33]. The fragment $A \beta$ $(1-11 / 12)$ detected in soluble fractions [34] and generated following catabolism of full length $A \beta$ by BACE2 [8] is predicted to react with $6 \mathrm{E} 10$, Fig. $2 \mathrm{~b}$, but this has not been investigated. 


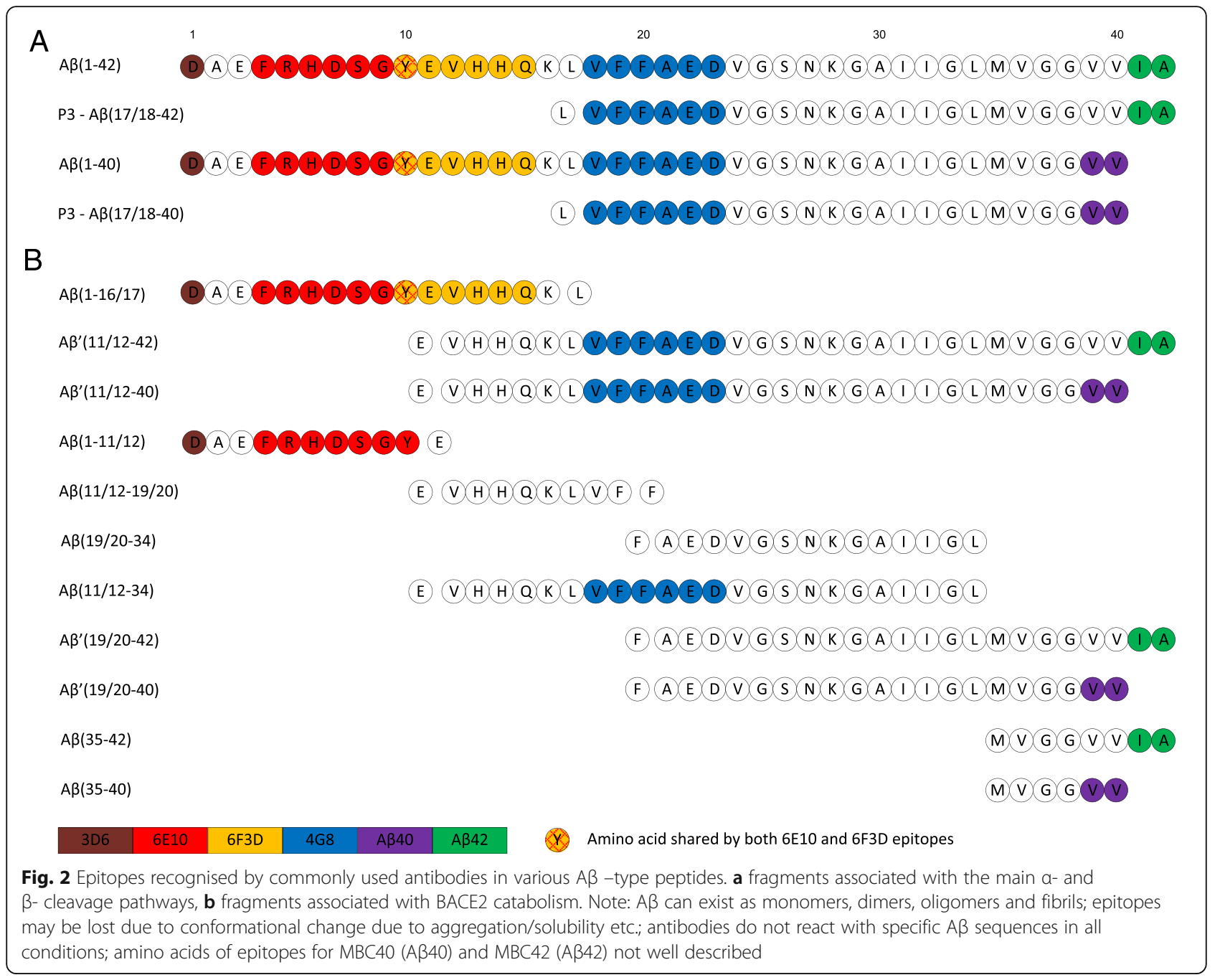

Antibody 6F3D recognises an $\mathrm{N}$-terminal epitope present in full length $A \beta 42, A \beta 40$ and is predicted to react with $A \beta(1-16 / 17)$ but unlike $6 \mathrm{E} 10$, not $A \beta$ (1-11/ 12). Neither $6 \mathrm{~F} 3 \mathrm{D}$ nor $6 \mathrm{E} 10$ are predicted to react with P3-type peptides, equivalent to $A \beta(16 / 17-40 / 42)$ derived from sequential $\alpha$ - and $\gamma$ - cleavages of APP [1] that lack the amino acid sequence of the epitope. As such $6 \mathrm{E} 10$ and 6 F3D represent initial $\beta$-cleavage but do not inform on C-terminal variability due to carboxypeptidase activities of $\gamma$-cleavage [35]. This may be generally applicable to other antibodies recognising $\mathrm{N}$-terminal epitopes, such as 6C6, which also recognise $\mathrm{N}$-terminal epitopes [34]. Interpretation could be further complicated by reactivities with shorter $\mathrm{N}$-terminal peptides derived from full length $\mathrm{A} \beta$ by catabolism or additional processing of membrane bound CTF and shorter C-terminal endings, seen in conditioned media from cell culture [22].

Antibodies specific for C-terminals ending at aa $A \beta 40$ or $A \beta 42$ are traditionally interpreted as representing $A \beta$.
However, antibodies specific for $\mathrm{A} \beta 40 \mathrm{MBC} 40$ and $\mathrm{A} \beta 42$ MBC40 were noted to react with shorter $\mathrm{N}$-truncated A $\beta$ peptides including P3 (40) and P3 (42) respectively [29]. Antibodies reactive with either $A \beta 40$ or $A \beta 42$ are also predicted to react with shorter peptides from $\mathrm{A} \beta$ catabolism, Fig. 2, though this will depend on whether the exact epitope recognised is still present in the shorter sequence. Characterisation of epitopes recognised by antibodies in general is a widely held concern. While studies using antibodies raised against $A \beta 40$ or $A \beta 42$ will monitor the specificity of C-terminal epitopes or cross reactivity with full length APP [36], very few account for N-terminal variation. Therefore we cannot be certain that any antibody thought to represent $A \beta 40$ or $A \beta 42$ derived from sequential $\beta$ - and $\gamma$ - cleavages actually represents full length rather than peptides from other cleavages lacking the $\mathrm{N}$-terminal epitopes. Immunoreactivity with the antibodies recognising fragments ending in either aa40 or aa42 of $A \beta$ should be 
Table 1 Epitopes and cross reactivities of selected antibodies raised against $A \beta$

\begin{tabular}{|c|c|c|c|}
\hline Antibody & Epitope & Cross Reactivity & Ref \\
\hline $4 \mathrm{G} 8$ & $\begin{array}{l}\text { Raised against synthetic peptide } A \beta 17-24 \text {; epitope lies } \\
\text { within aa 18-23; recognises multiple forms of } A \beta\end{array}$ & $\begin{array}{l}\text { Cross reacts with APP770 and P3; reacts with conformational } \\
\text { epitope of aggregated fibrils including a-synuclein }\end{array}$ & {$[29,38,39]$} \\
\hline $6 \mathrm{E} 10$ & $\begin{array}{l}\text { Raised against } A \beta 1-17 \text {; epitope lies within aa } 4-9 \text {; } \\
\text { recognises } A \beta \text { with intact } N \text {-terminal epitope }\end{array}$ & $\begin{array}{l}\text { Cross reacts with APP and A } 3(1-16) \text {; No reaction predicted } \\
\text { with } \mathrm{P} 3\end{array}$ & {$[3,29]$} \\
\hline $6 \mathrm{~F} 3 \mathrm{D}$ & $\begin{array}{l}\text { Raised against synthetic peptide } A \beta 8-17 \text {; epitope lies } \\
\text { within aa } 10-15 \text {; recognises } A \beta \text { with intact } N \text {-terminal } \\
\text { epitope }\end{array}$ & Predicted to react with $A \beta(1-16)$; Does not react with P3 & {$[29,31]$} \\
\hline MBC40 (Aß40) & $\begin{array}{l}\text { Recognises C-terminal A } \beta \text { peptides ending at aa } 40 \text {; } \\
\text { epitope not well described }\end{array}$ & Cross reacts with $\mathrm{N}$-terminal truncated peptides including P3 & [29] \\
\hline MBC42 (Aß42) & $\begin{array}{l}\text { Recognises C-terminal A } \beta \text { peptides ending at aa } 42 \text {; } \\
\text { epitope not well described }\end{array}$ & Cross reacts with $\mathrm{N}$-terminal truncated peptides including P3 & [29] \\
\hline BS85 & $\begin{array}{l}\text { Raised against } A \beta(25-35) \text {; recognises } A \beta 38, A \beta 39 \text {, } \\
A \beta 40, A \beta 42 \text { and } A \beta 43 \text {; epitope not well described }\end{array}$ & Cross reacts with $\mathrm{N}$-terminal truncated peptides including P3 & [28] \\
\hline BC05 & $\begin{array}{l}\text { Raised against } A \beta \text { ( } 35-43 \text { ); recognises } A \beta 42 \text { and } \\
A \beta 43 \text {; epitope not well described }\end{array}$ & $\begin{array}{l}\text { Cross reacts with N-terminal truncated peptides including P3; } \\
\text { does not recognise } A \beta 40 ; \text { used in commercial ELISA kits for the } \\
\text { detection of } A \beta 42\end{array}$ & {$[28,44]$} \\
\hline BA27 & $\begin{array}{l}\text { Raised against } A \beta(1-40) \text { Recognises } A \beta 40 ; 100-1000 x \\
\text { more reactive with } A \beta 40 \text { than } A \beta 42 \text { and } A \beta 43 ; \text { epitope } \\
\text { not well described }\end{array}$ & $\begin{array}{l}\text { Cross reacts with N-terminal truncated peptides including P3; } \\
\text { used in commercial ELISA kits for the detection of A } 440\end{array}$ & [28] \\
\hline A $\beta$ N17 (Leu) & $\begin{array}{l}\text { Raised against P3 (40); recognises P3 (40) and synthetic } \\
\text { P3 (42) peptide; epitope not well described }\end{array}$ & Reactivity with insoluble, aggregated P3 (42) not confirmed & {$[28,42,57]$} \\
\hline \multirow[t]{2}{*}{ 3D6 } & $\begin{array}{l}\text { Raised against } A \beta \text { with } N \text {-terminal aspartic acid; epitope } \\
\text { not well described }\end{array}$ & $\begin{array}{l}\text { Does not cross react with SAPPs or full length APP; No reaction } \\
\text { predicted with P3; parent of Bapineuzumab; epitope not well } \\
\text { described }\end{array}$ & [53] \\
\hline & Raised against $A \beta$ (13-28); epitope not well described & Solanezumab & [53] \\
\hline
\end{tabular}

interpreted as representing fragments from $\gamma$-cleavage regardless of initial $\alpha$ - or $\beta$ - cleavages unless cross reactivity checks prove otherwise.

$\mathrm{A} \beta$ - type, P3-type, $\mathrm{A} \beta$,' equivalent to $\mathrm{A} \beta(11 / 12-4 \mathrm{x})$ released following cleavage by BACE2 and $\gamma$-cleavage [4] or following catabolism of the full length $A \beta$ peptide [8], and various fragments derived from catabolism share sequence homology, Fig. 2 and Table 1. In human kidney 293 cell culture medium, approximately $69 \%$ of peptides released following $\gamma$ - cleavage were found to be P3-type, around $20 \%$ are $A \beta$-type and $11 \%$ are $A \beta$ '-type [37] however, different expression systems may give different ratios and these ratios may not reflect the levels of expression in the human brain. Shorter fragments in Fig. 2, including $A \beta(11 / 12-19 / 20), A \beta$ (19/20-34), $A \beta$ (19/20-42), $A \beta$ (19/20-40), $A \beta$ (35-42) and $A \beta$ (35-40) are predicted from BACE2 catabolism of full length $A \beta$ [8]. These shorter $A \beta$-type peptide sequences have been largely neglected in $\mathrm{AD}$ research and their expression levels in human tissues remains to be fully described. No study to date has systematically characterised all these fragments in the human brain. $A \beta(1-4 x), P 3(17-4 x)$, $A \beta^{\prime}(11 / 12-x)$ and $A \beta^{\prime}(11 / 12-34)$ type peptides are predicted to react with the $4 \mathrm{G} 8$ antibody, reactive with an epitope within aa 18-23. Therefore 4G8 detects products from $\gamma$-cleavage irrespective of the initial primary cleavage but should not detect catabolic fragments following degradation of full length $A \beta(1-4 x)$ missing the intact epitope sequence. 4G8 also shares a conformational epitope with other fibril forming proteins including $\alpha$-synuclein [38] that is sequence independent.

While these epitopes are assumed to be sequence specific, this cannot be guaranteed. $A \beta$ exists in many aggregation states from monomers, dimers, oligomers and fibrils. These conformation changes can potentially lead to changes in the presentation of epitopes and neither $6 \mathrm{E} 10$ nor $4 \mathrm{G} 8$ were found to react with all samples of $A \beta$ when aggregated under various conditions [39]. Reactivity was found to change depending aggregation, suggesting that epitopes can be revealed or hidden by different conformations and at least two different aggregated conformations may be present depending on specific conditions. This study shows that antibodies reactive with $A \beta$-type peptides are both sequence and conformation dependent [39]. 4 G8 specifically was found not to react with $A \beta 40$ at higher molecular weight oligomers and reacted with high molecular weight $A \beta 42$ only when aggregated under conditions with agitation. Therefore 4G8 immunoreactivity cannot be assumed to visualise "total" A $\beta$.

\section{The use of antibodies in diagnosis and research}

$\mathrm{AD}$ diagnosis and research in the human brain depends on the use of antibodies reactive with $A \beta$. It is essential 
that results from studies across the world are comparable and attempts to standardise inter-laboratory comparisons of amyloid pathology [30, 40] have found that immunohistochemical approaches are more reliable than silver stain based techniques. Further, because 4G8 shows more $A \beta$ immunoreactive pathology than either $6 \mathrm{E} 10$ or $6 \mathrm{~F} 3 \mathrm{D}$, it has been recommended as the antibody of choice for diagnostic work to visualise deposits of $A \beta$ [30], perhaps implying that increased immunoreactivity represents increased sensitivity for $A \beta$. However, if we consider the reactivity of $4 \mathrm{G} 8$ with fragments from the wider APP proteolytic system, not all reactivity necessarily represents $A \beta$. Thal et al. [29] stained sequential sections from a case with extensive $A \beta$ pathology with 6E10, 6F3D, 4G8, MBC40 and MBC42 Table 1. They found strong reactivity of plaques with MBC42 and 4G8 but little reactivity with $\mathrm{MBC} 40$ and $6 \mathrm{~F} 3 \mathrm{D}$ suggesting that the majority of staining was due to $\mathrm{N}$-truncated peptides equivalent to P3 (A $\beta 17-42)$ [29]. However, this interpretation of the staining patterns is not straightforward as loss of staining with $6 \mathrm{~F} 3 \mathrm{D}$ could also reflect a change in aggregation state that hides the $6 \mathrm{~F} 3 \mathrm{D}$ epitope especially for $A \beta 42$ which may be more prone to aggregation and insolubility or may be lost due to membrane binding [41]. Therefore antibodies to N-terminal epitopes of $A \beta$, such as $6 \mathrm{~F} 3 \mathrm{D}$ and $6 \mathrm{E} 10$ may not be revealing all $\mathrm{A} \beta(1-4 \mathrm{x})$.

Over 40 soluble A $\beta$-type peptides are biologically present [22]. Interestingly, the peptide P3 (42), representing the peptide thought to be associated with neuropathology of diffuse senile plaques [29] is not listed in Table 2 in Wang et al 1996 [22] even though the use of 4 G8 as a capture antibody is predicted to react with it. This suggests that the more insoluble P3 (42) aggregated in plaques could adopt a significantly different conformation to P3 (40) found in the soluble compartment and this requires clarification.

The results obtained by Thal et al. $[29,31]$ are compatible with those using different monoclonal antibodies, BS85 reacting with multiple forms of $\mathrm{A} \beta, \mathrm{BC} 05$ - reacting with $A \beta 42 / 3$ and $B A 27$ - reacting with $A \beta 40$ in a different study that did not account for $\mathrm{N}$-terminal variation [28]. This study found similar reactivity profiles for BS85 and BC05, marking multiple cored and fleecy amyloid senile plaques whereas BA27, reactive for Cterminal $A \beta 40$, detected cored senile plaques only. In a follow-up study, Iwatsubo et al. [42] used an antibody raised against the $\mathrm{N}$-terminal of $\mathrm{P} 3$ to measure the deposition of P3 and found little reactivity, suggesting that P3 is not involved in neuropathological deposition. However as with $A \beta 42$, this could reflect the different solubilities and aggregation states of P3-type peptides where P3 (40) is seen in the soluble pool of fragments whereas P3 (42) is not [22]. It is important to note that synthetic peptides of soluble P3 (40) were used to select the Nterminal antibody $\mathrm{A} \beta \mathrm{N} 17$ (Leu) in this study and although reactivity was noted with P3 (42) in western blot analysis, the aggregation of the synthetic P3 (42) peptide was not considered. As with the reactivity of 6F3D with A 340 discussed above, the contributions of aggregation state of P3 (42) and consequent loss of epitope cannot be dismissed. Indeed these staining patterns may indicate that the epitopes contained in the N-terminal of P3 are solubility dependent and are lost in aggregated P3 (42), associated with diffuse amyloid deposition and therefore no reactivity in diffuse plaques with antibodies recognising P3 (40) or non-aggregated P3 (42) would be expected. This interpretation is compatible with the scant reactivity of $\mathrm{MBC} 40$ and BA27, showing no reactivity for peptides ending with aa40 [29, 42]. Consideration must be given to solubility and aggregation state when interpreting antibody reactivities.

A few studies explicitly account for antibody cross reactivities. Citron et al. [43] describe the reactivity of $\mathrm{R} 1280$ as " $a$ polyclonal antiserum raised against synthetic $A \beta_{1-40 \ldots}$ and precipitates $A \beta(4 \quad k D a), p 3$ ( $3 \mathrm{kDa}$ ), and small amounts of $A P P_{S}{ }^{\prime \prime}$ and in another paper [44] they explicitly describe the reactivities of the monoclonal antibody 21 F12 as immunoprecipitating $A \beta$ (42) and P3 (42), the monoclonal antibody $\mathrm{BCO} 5$ detecting $\mathrm{A} \beta$ (42) and P3 (42) and the polyclonal antibody C42 detecting $A \beta$ (42) and P3 (42). Watson et al. [45] note that both polyclonal R1280 and R1282 immunoprecipitate soluble $\mathrm{A} \beta, \mathrm{P} 3$ and related peptides. As already discussed Thal et al. [29] explicitly describe the reactivity of MBC40 with $\mathrm{A} \beta 40$ and P3 (40) and MBC42 with A 342 and P3 (42). However, few more recent studies explicitly account for antibody reactivity profiles with a potential for cross reactivities to confound interpretations of immunoreactivity patterns.

Study designs using a capture antibody reactive with epitopes within the first 16 amino acids of $A \beta$ to select only $A \beta$ peptides resulting from $\beta$-cleavage as an initial step e.g. Moore et al. $[3,46]$ leave any P3 type peptides unrecorded and not accounted for. Where studies use a capture antibody reactive with the $\mathrm{N}$-terminal of $A \beta$, further characterisation with antibodies detecting $\mathrm{C}$-terminal aa 40 or 42 can be interpreted as representing $A \beta 40$ or $A \beta 42$ from $\beta$-cleavage. However, a study using this approach to quantify $A \beta 40 / 42$ in wet tissues then investigated location using only antibodies reactive with A $\beta 42$ in formalin fixed, paraffin embedded tissues [34] where results have been interpreted as showing both quantity and location of $A \beta 42$. However, this study design is potentially confounded by cross reactivity with $\mathrm{P} 3$ (42) in formalin fixed, paraffin embedded tissue that has not been checked. Keeping experimental approaches consistent both within and between studies is a 
challenge but one that requires urgent attention. Some commercial ELISA kits use BA27 to detect $\mathrm{A} \beta 40$ and $\mathrm{BC} 05$ to detect $\mathrm{A} \beta 42$, however, since both these antibodies are known to also recognise P3 (40) and P3 (42) respectively, we cannot be certain that any results obtained are not confounded by P3. Antibody reactivity profiles with potentially similar peptides from the APP proteolytic system should always be checked.

\section{How do we best interpret the available evidence derived from antibody reactivities?}

Interpretation of the reactivities of antibodies immunoreactive with $\mathrm{A} \beta$-type peptides is not straightforward and is compounded by the lack of systematic definitions of $A \beta$-type peptides. On the one hand $A \beta$ is often discussed as a homogenous whole, where the different sequence lengths and aggregation states are collapsed under "A $\beta$ " as an umbrella concept. Yet, because the different fragments sequences and aggregation states show discrete behaviours, this umbrella concept may not be useful for more detailed research questions investigating the role (s) of $A \beta$ in disease pathways. Should each possible fragment derived from $\alpha-, \beta-$, and $\gamma^{-}$cleavages and $A \beta$ catabolism be experimentally controlled for in a systematic approach? The different behaviours of the A $\beta$-type and P3-type fragments depending on aggregation state suggest that this may be an important issue that has yet to be fully incorporated in experimental design. This is not straightforward as the contributions of each possible sequence can potentially vary with solubility and aggregation state, certainly increasing experimental costs as each fragment is controlled for.

Because 4G8 is increasingly recommended for diagnostic work [30], and because reactivity is interpreted as $\mathrm{A} \beta$ (umbrella concept) it is probable that the contributions of P3 (42) to neuropathological classifications have been hidden in current experimental designs and therefore neglected. However, not all laboratories use 4G8 and instead use $6 \mathrm{E} 10$ or $6 \mathrm{~F} 3 \mathrm{D}$, specific for N-terminal epitopes of $A \beta$ that do not detect P3-type fragments. These antibodies visualise qualitatively different aspects of $A \beta$ deposition, i.e. lacking contributions from P3-type fragments [31] potentially confounding comparisons between studies from different laboratories using different antibodies [29, 30]. If all laboratories were to use 4G8, this would potentially confound how we understand the deposition of specific $\mathrm{A} \beta$-species as it detects a wide range of fragments, not all necessarily $A \beta$. This confounding would also be relevant to the use of antibodies reactive with The $C$-terminal residues from $A \beta 40$ and $\mathrm{A} \beta 42$, as N-terminal variation is not detected. The only option to systematically detect specific peptides is to use multiple antibodies reacting with the different epitopes or use a capture antibody relevant to the experimental design, such as $4 \mathrm{G} 8$ as in [22] or $6 \mathrm{E} 10$ as in [3, 22] and then analyse any fragments further with for example, mass spectroscopy. However, it must be born in mind that a single antibody will not capture all possible $\mathrm{A} \beta$ or P3 type fragments in all aggregations states [39] and this must be explicitly accounted for in any experimental design. The different antigen retrieval methods [47], different profiles of A $\beta$-type fragments in soluble [22] and insoluble fractions and potential loss of epitopes due to aggregation state [39] add further difficulties in systematically characterising A $\beta$. A "panel" of antibodies to consistently and reliably characterise A $\beta$-type, P3-type and catabolic fragments in all aggregation states (monomer, dimer, oligomer and fibril) is not currently possible.

\section{Antibody reactivities and their relevance to APP proteolytic pathways and disease}

Contrary to our current understanding, the immunoreactivity profiles of commonly used antibodies do not correspond directly to APP cleavage pathways $[1,2,8]$, summarised in Fig. 1. Immunoreactivity of antibodies predicted to have a wide reactivity profile such as $4 \mathrm{G} 8$ and potentially those that react with $\mathrm{C}$-terminal epitopes representing aa40 or aa 42 cannot be interpreted as giving evidence for initial $\alpha$ - or $\beta$ - cleavages. Given that antibodies are central to AD research and biomarker development, it is not clear whether the antibodies currently being used to identify $\mathrm{C}$-terminals do indeed reflect $A \beta 40 / 42$ or whether signals are confounded by P3 (40/42). Additionally, very little account is taken of the different soluble and insoluble compartments, therefore P3 (42), present in neuropathological deposits, may not be present in soluble fractions and can be easily missed if only soluble fractions are investigated. How then do we best approach the search for reliable biomarkers for AD?

Various morphologies of $A \beta$ deposits have been noted and these differ in their immunoreactivity profiles [48] how immunoreactivity differences associate with the different pathological morphologies have not been systematically investigated with respect to clinical dementia status. The insoluble fragment P3 (42) may be a major constituent of diffuse amyloid deposition and may be relevant to disease pathways however, current approaches have almost completely neglected any contributions it might have. Cross reactivity of commonly used antibodies between the A $\beta, P 3$ type and catabolic peptides confounds our current understanding and may in part explain why clinical and neuropathological diagnoses of AD do not correspond well in the older population. To what extent a lack of understanding of the APP proteolytic system as a whole derives from a misunderstanding of antibody cross reactivities requires careful 
consideration. Neuropathological characterisation of human brain donations, essential to our understanding of $\mathrm{AD}$, requires re-evaluation.

Current immunotherapeutic approaches to target $\mathrm{A} \beta$ have used passive humanised antibodies to enhance removal of $A \beta$ from the brain with the aim of slowing or halting the progression of AD [49]. To date these have had little success [49-52]. Bapineuzumab, Table 1, is based on the monoclonal antibody 3D6 directed towards an N-terminal epitope and Solanezumab, directed at an epitope from the $A \beta(13-28)$ central region [53]. Given the uncertainty surrounding which fragments are responsible for disease progression we highlight here, we have to ask whether antibodies directed only at N-terminal epitopes of $\mathrm{A} \beta$, such as Bapineuzumab, would be expected to change disease course. Following the failure of both Bapineuzumab [51, 52] and Solanezumab [50] in phase III clinical trials, refinements to the therapeutic approach call for earlier, perhaps preventative, use of the antibodies during the prodromal phase of $\mathrm{AD}$, i.e. where a high amyloid signal is seen on MRI but before any cognitive change has occurred. However, the failure of these trials suggests that a return to basic science and a reevaluation of our current understanding of the role of $\mathrm{A} \beta$ in $\mathrm{AD}$ is also warranted. How prodromal $\mathrm{AD}$ relates to those in the oldest old who have extensive pathology after death but with intact cognitive function in life remains unclear. Clarification of the physiological roles [54-56] of the APP proteolytic system and all its fragments $[20,21]$ in both in disease and normal ageing in the human population is urgently required.

The implications arising from the cross reactivity of commonly used antibodies to $A \beta$ are profound. Cross reactivity may be hiding more complex relationships between $\mathrm{AD}$ and fragments from sequential $\alpha-, \beta$ - and $\gamma$ - cleavages that the current favoured model, the amyloid cascade hypothesis, cannot account for. If P3 is indeed involved in disease progression then a more flexible approach to understanding the relationships between all APP proteolytic fragments may be required and both the presenilin hypothesis $[18,19]$ and the APP matrix approach $[20,21]$ may be better guides to systematically investigate this complex proteolytic system.

\section{Conclusions}

The concept of $A \beta$ lacks clarity in terms of what we mean by $A \beta$ as a specific biological form and this is further confounded by antibody cross-reactivities. The different solubilities and aggregation states of proteolytic fragments from $\gamma$-cleavage and their catabolism add further complexity. These cross reactivities, often overlooked, require urgent attention by the $\mathrm{AD}$ research community. More than one antibody is required to adequately characterise $\mathrm{A} \beta$. We do not currently have reliable evidence to identify any specific APP proteolytic fragment as causal in AD progression. The correspondence between $A \beta$ immunoreactivity from any specific antibody, neuropathology and proposed APP cleavages is not clear and may in part explain the lack of correspondence between clinical and neuropathological diagnoses of dementia. These cross reactivities question current therapeutic approaches to reduce $A \beta$ via directed immunotherapies, call for a detailed re-analysis of biomarker results and call into question approaches aimed solely at reducing $\beta$-cleavage. A detailed consideration of anti-A $\beta$ antibody cross reactivities reveals significant uncertainty in our current understanding of the APP proteolytic system and how this relates to disease with profound implications for current research and therapeutic strategies.

\section{Acknowledgments}

Not applicable.

Funding

CB and SH are supported by an NIHR Senior Investigator award awarded to CB.

Availability of data and materials

Not applicable.

Authors' contributions

$\mathrm{SH}$ conducted the review and wrote the article with contributions from CB. All authors read and approved the final manuscript.

Competing interests

The authors declare that they have no competing interests.

Consent for publication

Not applicable.

Ethics approval and consent to participate Not applicable.

Received: 18 October 2016 Accepted: 13 January 2017

Published online: 26 January 2017

\section{References}

1. Turner PR, et al. Roles of amyloid precursor protein and its fragments in regulating neural activity, plasticity and memory. Prog Neurobiol. 2003;70(1):1-32

2. Selkoe DJ. Normal and abnormal biology of the beta-amyloid precursor protein. Annu Rev Neurosci. 1994;17:489-517.

3. Moore $\mathrm{S}$, et al. APP metabolism regulates tau proteostasis in human cerebral cortex neurons. Cell Rep. 2015;11(5):689-96.

4. Farzan $M$, et al. BACE2, a beta -secretase homolog, cleaves at the beta site and within the amyloid-beta region of the amyloid-beta precursor protein. Proc Natl Acad Sci U S A. 2000;97(17):9712-7.

5. Willem $\mathrm{M}$, et al. eta-secretase processing of APP inhibits neuronal activity in the hippocampus. Nature. 2015;526(7573):443-7.

6. Andrew RJ, et al. A Greek tragedy: the growing complexity of Alzheimer amyloid precursor protein proteolysis. J Biol Chem. 2016;291(37):19235-44.

7. Park SA, et al. Mechanism of cytotoxicity mediated by the C31 fragment of the amyloid precursor protein. Biochem Biophys Res Commun. 2009;388(2):450-5

8. Abdul-Hay SO, et al. Identification of BACE2 as an avid abeta-amyloiddegrading protease. Mol Neurodegener. 2012;7:46.

9. Schellenberg GD, Montine TJ. The genetics and neuropathology of Alzheimer's disease. Acta Neuropathol. 2012;124(3):305-23.

10. St George-Hyslop PH, Petit A. Molecular biology and genetics of Alzheimer's disease. C R Biol. 2005;328(2):119-30. 
11. Hyman BT, et al. National institute on aging-Alzheimer's association guidelines for the neuropathologic assessment of Alzheimer's disease. Alzheimers Dement. 2012;8(1):1-13.

12. Montine TJ, et al. National institute on aging-Alzheimer's association guidelines for the neuropathologic assessment of Alzheimer's disease: a practical approach. Acta Neuropathol. 2012;123(1):1-11.

13. Hardy J. Alzheimer's disease: the amyloid cascade hypothesis: an update and reappraisal. J Alzheimers Dis. 2006;9(3 Suppl):151-3.

14. Hardy JA, Higgins GA. Alzheimer's disease: the amyloid cascade hypothesis. Science. 1992;256(5054):184-5.

15. Hardy J, Selkoe DJ. The amyloid hypothesis of Alzheimer's disease: progress and problems on the road to therapeutics. Science. 2002;297(5580):353-6.

16. Klein WL, Krafft GA, Finch CE. Targeting small abeta oligomers: the solution to an Alzheimer's disease conundrum? Trends Neurosci. 2001;24(4):219-24.

17. Walsh DM, Selkoe DJ. Deciphering the molecular basis of memory failure in Alzheimer's disease. Neuron. 2004;44(1):181-93.

18. Shen J. Function and dysfunction of presenilin. Neurodegener Dis. 2014;13(2-3):61-3.

19. Shen J, Kelleher 3rd RJ. The presenilin hypothesis of Alzheimer's disease: evidence for a loss-of-function pathogenic mechanism. Proc Natl Acad Sci U S A. 2007;104(2):403-9.

20. Hunter S, Brayne C. Relationships between the amyloid precursor protein and its various proteolytic fragments and neuronal systems. Alzheimers Res Ther. 2012;4(2):10.

21. Hunter S, Martin S, Brayne C. The APP proteolytic system and its interactions with dynamic networks in Alzheimer's disease. Methods Mol Biol. 2016;1303:71-99.

22. Wang $R$, et al. The profile of soluble amyloid beta protein in cultured cell media. Detection and quantification of amyloid beta protein and variants by immunoprecipitation-mass spectrometry. J Biol Chem. 1996;271(50): 31894-902.

23. Welzel AT, et al. Secreted amyloid beta-proteins in a cell culture model include $\mathrm{N}$-terminally extended peptides that impair synaptic plasticity. Biochemistry. 2014;53(24):3908-21.

24. Brayne C, et al. Neuropathological correlates of dementia in over-80-yearold brain donors from the population-based Cambridge city over-75 $\mathrm{s}$ cohort (CC75C) study. J Alzheimers Dis. 2009:18(3):645-58.

25. Pathological MRC-CFAS. Correlates of late-onset dementia in a multicentre, community-based population in England and wales. Neuropathology group of the medical research council cognitive function and ageing study (MRC CFAS). Lancet. 2001;357(9251):169-75.

26. Corrada MM, Berlau DJ, Kawas CH. A population-based clinicopathological study in the oldest-old: the 90+ study. Curr Alzheimer Res. 2012;9(6):709-17.

27. Baker M. Reproducibility crisis: blame it on the antibodies. Nature. 2015:521(7552):274-6.

28. Iwatsubo T, et al. Visualization of a beta $42(43)$ and a beta 40 in senile plaques with end-specific a beta monoclonals: evidence that an initially deposited species is a beta 42(43). Neuron. 1994;13(1):45-53.

29. Thal DR, et al. Amyloid beta-protein (abeta)-containing astrocytes are located preferentially near $\mathrm{N}$-terminal-truncated abeta deposits in the human entorhinal cortex. Acta Neuropathol. 2000;100(6):608-17.

30. Alafuzoff I, et al. Inter-laboratory comparison of neuropathological assessments of beta-amyloid protein: a study of the BrainNet Europe consortium. Acta Neuropathol. 2008:115(5):533-46.

31. Thal DR, et al. Fleecy amyloid deposits in the internal layers of the human entorhinal cortex are comprised of N-terminal truncated fragments of abeta. J Neuropathol Exp Neurol. 1999;58(2):210-6.

32. Hernandez-Guillamon $M$, et al. Sequential amyloid-beta degradation by the matrix metalloproteases MMP-2 and MMP-9. J Biol Chem 2015;290(24):15078-91

33. Portelius $E$, et al. Novel abeta isoforms in Alzheimer's disease - their role in diagnosis and treatment. Curr Pharm Des. 2011;17(25):2594-602.

34. Seubert $P$, et al. Isolation and quantification of soluble Alzheimer's betapeptide from biological fluids. Nature. 1992;359(6393):325-7.

35. Fernandez MA, et al. Alzheimer presenilin-1 mutations dramatically reduce trimming of long amyloid beta-peptides (abeta) by gamma-secretase to increase 42-to-40-residue abeta. J Biol Chem. 2014;289(45):31043-52.

36. Wang J, et al. The levels of soluble versus insoluble brain abeta distinguish Alzheimer's disease from normal and pathologic aging. Exp Neurol. 1999; 158(2):328-37.
37. Haass C, et al. Mutations associated with a locus for familial Alzheimer's disease result in alternative processing of amyloid beta-protein precursor. J Biol Chem. 1994;269(26):17741-8.

38. Hatami A, Monjazeb S, Glabe C. The anti-amyloid-beta monoclonal antibody 4G8 recognizes a generic sequence-independent epitope associated with alpha-synuclein and islet amyloid polypeptide amyloid fibrils. J Alzheimers Dis. 2015;50(2):517-25.

39. Hatami A, et al. Monoclonal antibodies against Abeta42 fibrils distinguish multiple aggregation state polymorphisms in vitro and in Alzheimer disease brain. J Biol Chem. 2014;289(46):32131-43.

40. Alafuzoff I, et al. Interlaboratory comparison of assessments of Alzheimer disease-related lesions: a study of the BrainNet Europe consortium. J Neuropathol Exp Neurol. 2006:65(8):740-57.

41. Yanagisawa $\mathrm{K}$, et al. Fractionation of amyloid beta-protein (a beta) in Alzheimer's disease and Down's syndrome brains. Presence of membranebound a beta. Ann N Y Acad Sci. 1996;786:184-94.

42. Iwatsubo T, et al. Full-length amyloid-beta (1-42(43)) and amino-terminally modified and truncated amyloid-beta 42(43) deposit in diffuse plaques. Am J Pathol. 1996;149(6):1823-30.

43. Citron $\mathrm{M}$, et al. Excessive production of amyloid beta-protein by peripheral cells of symptomatic and presymptomatic patients carrying the swedish familial Alzheimer disease mutation. Proc Natl Acad Sci U S A. 1994;91(25):11993-7.

44. Citron $\mathrm{M}$, et al. Evidence that the 42- and 40-amino acid forms of amyloid beta protein are generated from the beta-amyloid precursor protein by different protease activities. Proc Natl Acad Sci U S A. 1996:93(23):13170-5.

45. Watson DJ, Selkoe DJ, Teplow DB. Effects of the amyloid precursor protein Glu693-> Gln 'Dutch' mutation on the production and stability of amyloid beta-protein. Biochem J. 1999;340(Pt 3):703-9.

46. Sollvander $\mathrm{S}$, et al. Accumulation of amyloid-beta by astrocytes result in enlarged endosomes and microvesicle-induced apoptosis of neurons. Mol Neurodegener. 2016;11(1):38.

47. Aho $L$, et al. Immunohistochemical visualization of amyloid-beta protein precursor and amyloid-beta in extra- and intracellular compartments in the human brain. J Alzheimers Dis. 2010;20(4):1015-28.

48. Thal DR, et al. Sequence of abeta-protein deposition in the human medial temporal lobe. J Neuropathol Exp Neurol. 2000:59(8):733-48.

49. Panza F, et al. Emerging drugs to reduce abnormal beta-amyloid protein in Alzheimer's disease patients. Expert Opin Emerg Drugs. 2016;21(4):377-91.

50. Doody RS, et al. Phase 3 trials of solanezumab for mild-to-moderate Alzheimer's disease. N Engl J Med. 2014;370(4):311-21.

51. Salloway $\mathrm{S}$, et al. Two phase 3 trials of bapineuzumab in mild-to-moderate Alzheimer's disease. N Engl J Med. 2014;370(4):322-33.

52. Vandenberghe $\mathrm{R}$, et al. Bapineuzumab for mild to moderate Alzheimer's disease in two global, randomized, phase 3 trials. Alzheimers Res Ther. 2016;8(1):18

53. Bouter $Y$, et al. Abeta targets of the biosimilar antibodies of bapineuzumab, crenezumab, solanezumab in comparison to an antibody against ntruncated abeta in sporadic Alzheimer disease cases and mouse models. Acta Neuropathol. 2015;130(5):713-29.

54. Castellani RJ, et al. Reexamining Alzheimer's disease: evidence for a protective role for amyloid-beta protein precursor and amyloid-beta. J Alzheimers Dis. 2009;18(2):447-52.

55. Castellani RJ, et al. Alzheimer disease pathology as a host response. J Neuropathol Exp Neurol. 2008:67(6):523-31.

56. Bishop GM, Robinson SR. Physiological roles of amyloid-beta and implications for its removal in Alzheimer's disease. Drugs Aging. 2004;21(10):621-30.

57. Saido TC, et al. Amino- and carboxyl-terminal heterogeneity of beta-amyloid peptides deposited in human brain. Neurosci Lett. 1996;215(3):173-6. 